\title{
The Effect of Electronic Module Utilization for Biomass Briquettes Experiment using Cocoa Shells and Sea Mango to Vocational School Students
}

\author{
Asep Bayu Dani Nandiyanto*, Agus Tendi Ahmad Bustomi, Yatti Sugiarti, Gabriela Chelvina Santiuly \\ Girsang \\ Universitas Pendidikan Indonesia, Jl. Dr. Setiabudi No. 229 Bandung, Indonesia \\ nandiyanto@upi.edu, tomi@upi.edu, attisugiarti5@upi.edu,gabrielachelvina@upi.edu
}

\begin{abstract}
The aims of this study are to identify the best carbon particle size and composition variations and to identify differences in student learning outcomes using demonstration experimental methods with learning video and e-module about the making of cocoa (Theobroma cacao L) shell and sea mango (Cerbera manghas) based bio charcoal briquettes. Briquetting process is carried out by drying raw materials, carbonizing, grinding, sieving, briquetting, and drying. Thirty agribusiness vocational students are selected as the subject to see the effectiveness of learning video and e-module for understanding the bio charcoal briquetting process. Students' understanding is assessed by pretest, posttest after learning with a video, and posttest after learning with e-module. The results show that briquettes with high sea mango concentrations have a high burning rate, water boiling test, and low specific fuel consumption. Briquettes containing small particle sizes have high values of relaxed density, relaxation ratio, and percentage of durability index. Based on the result, it can be concluded that the e-module is more effective than learning video for the student because it can cover wider and deeper materials. However, giving learning video to the students is still necessary so they may have a better visual experience regarding the briquetting process.
\end{abstract}

Keywords: Bio Charcoal Briquettes, Cocoa Shells, Sea mango, E-module, Learning Video

\author{
Corresponding Author \\ * Departemen Pendidikan Kimia, Universitas \\ Pendidikan Indonesia, J1. Dr. Setiabudhi No. 229 \\ Bandung, Indonesia \\ *nandiyanto@upi.edu
}

\section{Introduction}

An electronic module (e-module) is a module distributed in electronic media that has a similar function as the physical module. E-module is used as a learning media that contains learning materials, methods, and learning evaluation that are practically designed to attract students' interests in learning (Syahrial, 2020; Seidel, 2012; Riedl, 1977; Wibowo, 2018; Istuningsih, Baedhowi, and Sangka, 2018). Naturally, the elearning module has a self-instruction that only covers one learning material, which allows students to concentrate only on the material being taught (Asrial, 2019). The use of electronic module can attract students to the learning process as it can be accessed anytime and anywhere. E-module assists teachers and students in the distance learning process when adequate equipment and facilities are accessible (Syahrial, 2020), and teachers can easily engage in activities with students from various locations (Fourlilla and Fauzi, 2019).

However, the e-module has its drawback as the visual content displayed is limited and the visual images are less enticing (Suarsana, 2013). Therefore, supporting learning media is required. The more sensory organs used to acquire and interpret information, the more likely the information will be comprehended and preserved in memory. This is based on the study conducted by Nasution (2011) that $90 \%$ of learning results are obtained by visual senses and only $5 \%$ by auditory sense, and $5 \%$ by other senses. In addition, the learning acquisition results through sight are around $75 \%$, hearing sense $13 \%$ and by other senses approximately $12 \%$ (Dale, 2012). Thus, additional media for improving students' understanding is crucial (Nandiyanto, Asyahidda, Danuwijaya, Abdullah, Amelia, Hudha, and Aziz, 2018). One of the media that can be used is learning video. A video will encourage students to understand the content, energize dynamic collaboration, and provide students with an additional benefit. Learning videos are to be used as components of online learning, allowing understudy to memorize freely (Bjork, R. A., Dunlosky, J., and Kornell, N., 2013; Brame, 2016; Schacter, D. L., and Szpunar, K. K., 2015). The benefit of electronic learning media is to 
encourage the delivery of learning material from teachers to students (Sutirman, 2019).

Learning by using e-modules and learning videos are expected to help students achieve learning outcomes during the pandemic as what we are experiencing nowadays. Vocational school students require practical and cognitive skills although they study online. Agribusiness of Agricultural Products Processing is one of the majors in agribusiness vocational school where students are required to have competency in practical and cognitive knowledge regarding the processing of the agricultural product. One of the subjects that needs to be acquired is agricultural waste processing. Generally, the agricultural waste process is limited to the processing of agricultural waste into handicrafts, decorations, and food products. Processing agricultural waste into non-food products particularly heat energy sources has not been conducted because there is limited literature or learning module that focuses on it.

Bio-charcoal briquettes are solid fuels produced from the remnants of organic materials that have undergone a process of pyrolysis and compression. Bio-charcoal briquettes can replace the use of firewood because it will produce less smoke than wood when it is burned (Hambali, 2007). One type of biomass resource that has not been explored is cocoa (Theobroma cacao L) shell waste and sea mango (Cerbera manghas). Cocoa shells have a calorific value that meets the fuel specifications which is $4060 \mathrm{cal} / \mathrm{gram}$. According to literature (Hasan, Tedja, Riani, and Sugiarti, 2016; BenGhedalia, Daniel., and Joshua Miron., 1981), sea mango contains $52.59 \%$ of cellulose, $17.15 \%$ of hemicellulose, and $30.26 \%$ of lignin. Therefore, sea mango can also be used as a combination of cocoa shells to create briquettes.

The literature that develops e-module for the production of bio-charcoal briquettes based on cocoa shells and sea mango is still very limited. Some researchers have done briquetting for the sample of the pure cocoa shells, cocoa shells with tropical almond leaves, and sea mango with coconut shells (Martynis Sundari, and Sari, 2012; Rizaldi, Budiman, and Moonti, 2019; Suryani and Dahlan, 2012). Therefore, the present study focuses on the production of bio charcoal from cocoa shell and sea mango. This study aims to determine the learning outcomes of the vocational students in agribusiness processing of agricultural products regarding the bio charcoal briquettes production using learning video and e-module. The method used is the demonstration experimental method. The demonstration experiment approach emphasizes the ability of students to observe, demonstrate, and conduct an experiment and is appropriate for the production of bio charcoal briquettes that can be distributed in instructional video learning media and emodule.

\section{Method}

\subsection{Briquette Making}

In this study, we used cacao shell waste (taken from a cocoa plantation in Sumedang), sea mango (taken from Bandung City), tapioca flour, and water.
The cocoa shells and sea mango waste are cut using a knife with a $5 \times 5 \mathrm{~cm}$ size, dried using an electrical furnace $\left(85-105^{\circ} \mathrm{C} ; 4-6 \mathrm{~h}\right)$, and carbonized $\left(250-300^{\circ} \mathrm{C} ; 2-3 \mathrm{~h}\right)$. The electrical furnace/oven is used to minimize the air entering the oven to minimize oxidation. When the ingredients have become charcoal, the cocoa shell charcoal, and sea mango charcoal are saw-milled and sieve using a Tyler scene with specific particle sizes $(1000,600$, and $250 \mu \mathrm{m})$. After sieving, cocoa charcoal powder, sea mango charcoal powder, and tapioca flour are mixed accordingly to the specific weight of the mixture as shown in Table 1 . Then, add the boiling water to the dried ingredients and mix until the dough is smooth. The adhesive or binder composition is standardized into $20 \%$ of the total weight of the mixture. The briquettes are then molded $(\mathrm{d}=3.5 \mathrm{~cm} ; \mathrm{t}=1 \mathrm{~cm})$ and dried (85-120 $\left.{ }^{\circ} \mathrm{C} ; 3-4 \mathrm{~h}\right)$.

Several testing measurements are done including compressed density (CD), relaxed density (RD), relaxation ratio (RR), percentage of moisture content (PMC), percentage of water resistance index (PWRI), water boiling test (WBT), burning rate (BR), specific fuel consumption (SFC), and percentage of durability index (PDI).

Table 1. Composition of Briquettes

\begin{tabular}{cccc}
\hline $\begin{array}{c}\text { Powder Material Ratio } \\
\text { cacao: sea mango: tapioca }\end{array}$ & $\mathbf{1 0 0 0} \boldsymbol{\mu \mathbf { m }}$ & $\begin{array}{c}\text { Particle size } \\
\mathbf{6 0 0} \boldsymbol{\mu m}\end{array}$ & $\mathbf{2 5 0} \boldsymbol{\mu m}$ \\
\hline $9: 1: 2$ & A 18 & A 34 & A 60 \\
$8: 2: 2$ & B 18 & B 34 & B 60 \\
$7: 3: 2$ & C 18 & C 34 & C 60 \\
$6: 4: 2$ & D 18 & D 34 & D 60 \\
5: $5: 2$ & E 18 & E 34 & E 60 \\
\hline
\end{tabular}

\subsection{Research Subject}

The subject of this research is 30 second-year students of the vocational schools in Garut Regency, Indonesia. The research was conducted in November 2020.

\subsection{Teaching Method}

The experimental demonstration method is conducted by providing a pretest, briquette making instructional video, posttest, briquette making e-module, and posttest to 30 students at vocational school majoring in agribusiness processing of agricultural products (APHP) to assess the development of students learning outcomes. In order to assess the differences in the learning outcomes, the data is analyzed using the normality test, homogeneity test, and independent T-test.

This research is conducted in five stages as mentioned in previous research (Nandiyanto, A. B. D., Raziqi, G. Y., Dallyono, R., and Sumardi, K., 2020). Each stage of teaching is evaluated and analyzed using statistical testing in the SPSS application. The teaching stages of making bio charcoal briquettes are described as follows.

I. As a pretest, students are assessed via Google form to find students current knowledge

II. Students then are given a learning instructional video about making bio-charcoal briquettes. During the teaching process, particularly in experimental 
demonstrations, students are asked to concentrate on and carefully observe the phenomena that occur in the learning instructional video.

III. Students are given a posttest to evaluate their knowledge after learning the briquette through instructional video media.

IV. Students are presented with an e-module for making bio-charcoal briquettes, and students are asked to learn and understand the process of creating bio-charcoal briquettes.

V. Students are assigned a posttest to evaluate students' understanding after learning how to create bio charcoal briquettes through video media and emodule.

\subsection{Making Learning Instructional videos and e-Module}

The learning instructional video is made by documenting the stages of the production process of bio charcoal briquettes. Then, the instructional video documentation will be provided. A topic on the oxidation of bio-charcoal briquettes based on cocoa and sea mango shells is added.

The e-module is arranged following the guidance from guidance released by the Indonesian Ministry of Education and Culture (Direktorat Pembinaan SMA. Ditjen Pendidikan Dasar dan Menengah, 2017). E-module is prepared by the following steps.

I. Analysis of Requirement Stage

1) Design module based on the lesson implementation plan

2) The lesson plan for e-module is a lesson plan specifically designed to enable students to learn independently.

3) The e-module content covers the materials required to grasp the basic competencies, indicators of competency achievement, learning materials, learning activities, and assessment references

4) Design the e-module chapter.

5) Design the e-module titles. The name or title of the module should be modified to the competencies on the syllabus and the lesson plans.

II. Design Stage

1) Framework decision (cover, title, subject name, topic/learning materials, grade, author, table of content, glossaries, introduction, basic competencies, and core competencies, module guidance, learning objectives, material description, summary, assignment, practice, selfassessment, evaluation, answer key and scoring guidance, references and attachments).

2) Performance objective decision.

3)Evaluation system (scheme, method, and tools) decision.

4) Components decision: competency, brief description, estimated time, and references.

5) Designing the e-module.

\subsection{Evaluation of Learning Instructional videos and e- Module}

After learning using the instructional video and the emodule, several assessments such as pretest, teaching using instructional video, followed by posttest after learning with the instructional video, learning with e-module, and posttest after learning using e-module are conducted to assess students' comprehension.

The learning outcomes assessment is analyzed quantitatively. Students' demographic data including names, student identification number, IQ level, and the average score on science subjects (Chemistry, Biology, Mathematics, Physics, and Vegetable Processing Technology) is collected. Pretest and posttest are provided through Google form, which includes 15 questions about the process of making bio charcoal briquettes, and each correct answer values 1 , and the maximum score is 100 . The calculation is shown in Equation 1.

$$
N t=\frac{n \times 100}{\text { total students }}
$$

$N t$ is the average value of the correctly answered questions, and $n$ is the number of questions answered correctly by each student.

\section{Results and Discussion}

\subsection{Experimental Results}

Bio charcoal briquette production is shown in Figure 1. The analysis results of compressed density (CD) shown in Figure 2. From Figure 2 it is seen that the higher the sea mango mixture, the compressed density value tends to decrease. This is because the sample with a particle size of $1000 \mu \mathrm{m}$ has a high-density value of wet briquettes, which is $1.44 \mathrm{~g} / \mathrm{cm}^{3}$. Briquettes with a particle size of $1000 \mu \mathrm{m}$ have a large void fraction which can be filled by water. This result is in good agreement with the literature which states that the smaller the particle size, the smaller the spaces between particles (Setiowati and Tirono, 2014).

The results of relaxed density (RD) analysis are shown in Figure 3. The sample with a particle size of $250 \mu \mathrm{m}$ has a high relaxed density value of $0.86 \mathrm{~g} / \mathrm{cm}^{3}$. This is because the particle spaces in the $250 \mu \mathrm{m}$ briquette are smaller so that the briquettes are denser.

The result of the relaxation ratio is shown in Figure 4. Samples with a particle size of $1000 \mu \mathrm{m}$ have a fairly high RR value of $2.19 \mathrm{~g} / \mathrm{cm}^{3}$ because the particles in the briquette are more difficult to seal and have a higher void fraction (Priyanto, Hantarum, and Sudarno, 2018). The pores density affects evaporation when drying which affects the drying time.

Briquette moisture value is shown in Figure 5. There is no direct correlation between the ratio of the sea mango content with the moisture of the briquettes. The moisture content is determined by the drying process which is influenced by drying time and particle size. A larger particle size means a higher void fraction as such the moisture will easily evaporate (Setiowati and Tirono, 2014). Thus, the drying time will be shorter. 


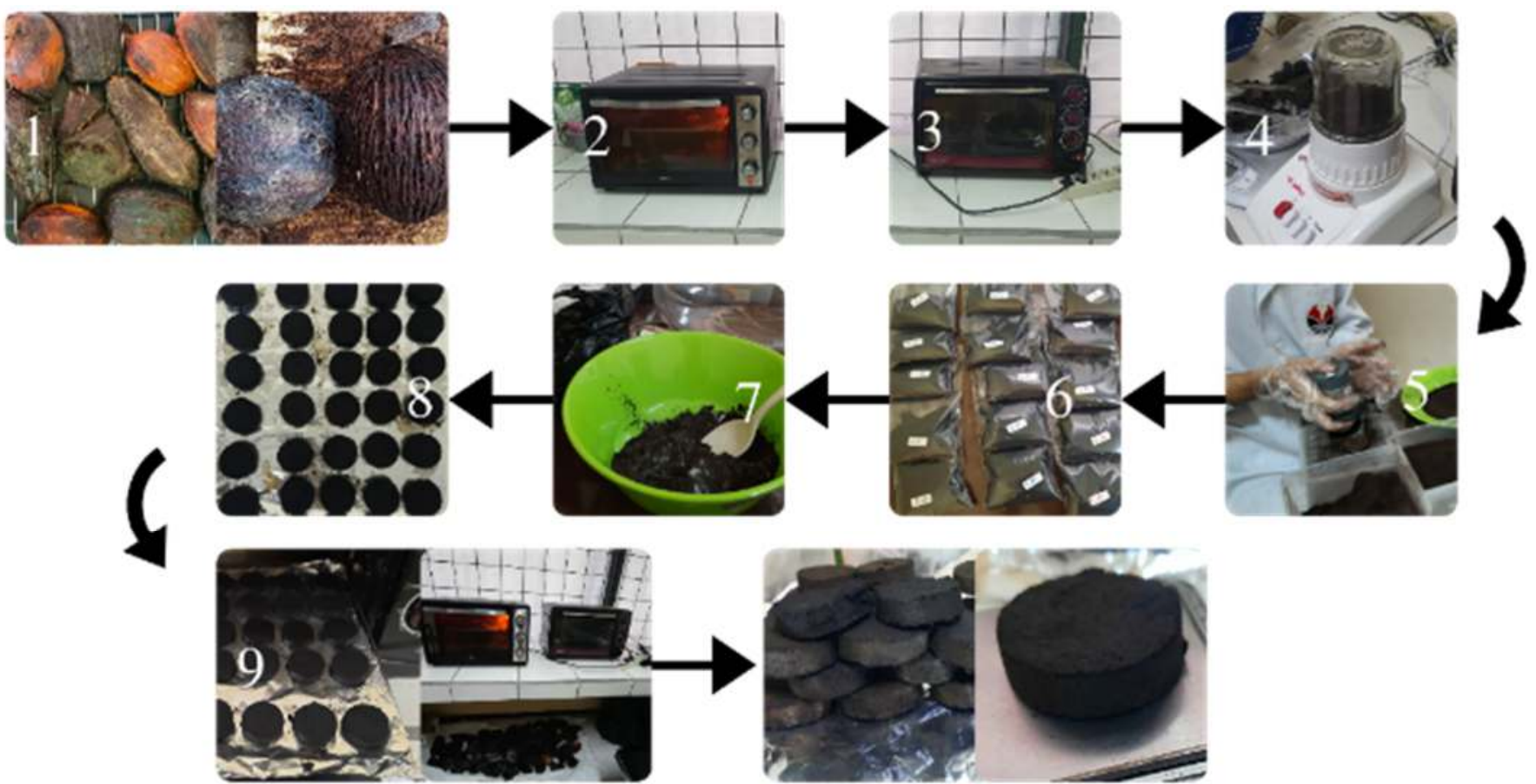

Fig 1. The Process of Making Briquettes

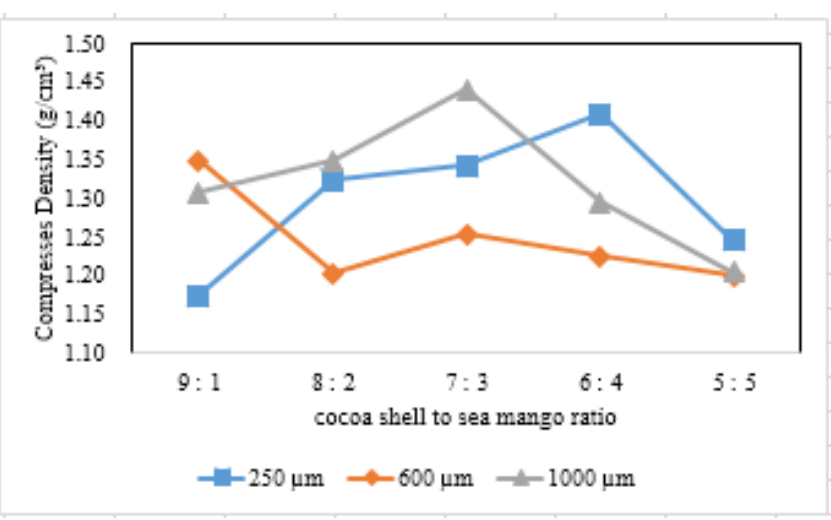

Fig. 2 Compressed density

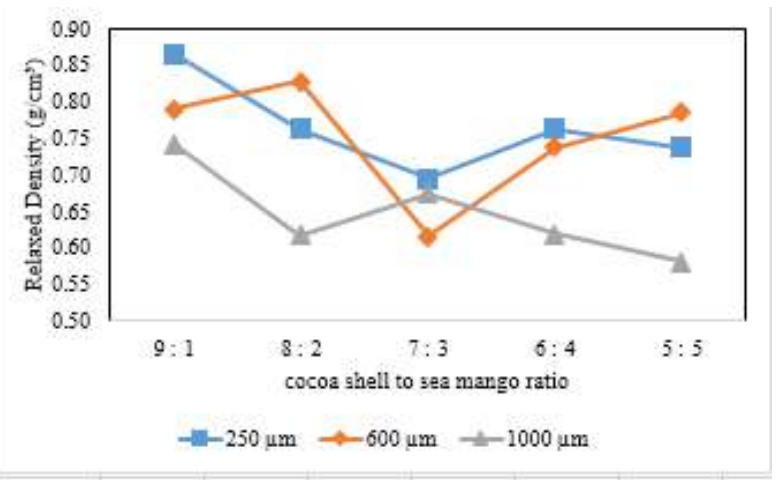

Fig. 3 Relaxed density

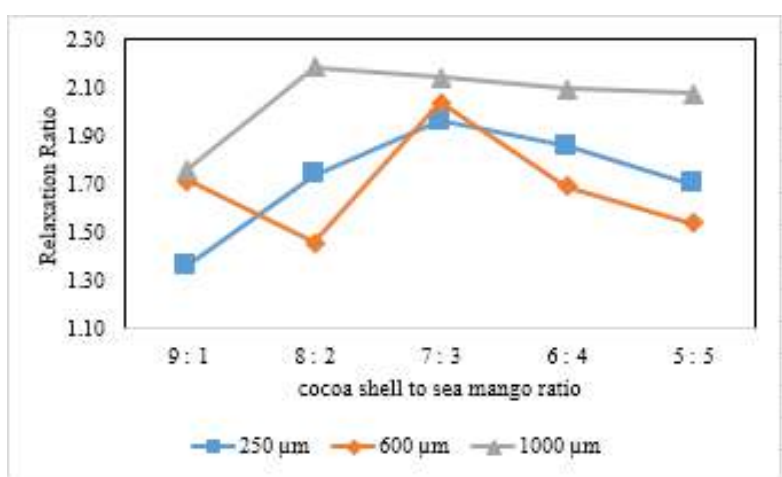

Fig. 4 Relaxation ratio

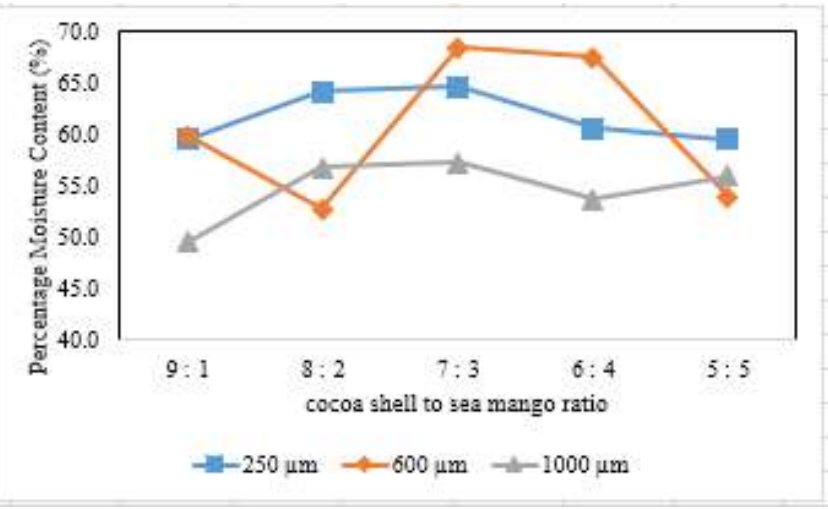

Fig. 5 Percentage moisture content 
The results of the durability index percentage are shown in Figure 6. From Figure 6, it is seen that briquettes with a particle size of less than $1000 \mu \mathrm{m}$ have a high average value of durability. Briquettes with a particle size of $600 \mu \mathrm{m}$ have a percentage of durability index (PDI) of $98 \%$ and briquettes with particle sizes of $250 \mu \mathrm{m}$ have PDI of $97 \%$. However, the average durability value for briquettes with a particle size of $1000 \mu \mathrm{m}$ is lower, which is $94 \%$. This is in line with the literature which states that the larger the particle size, the greater the compressive strength (Damayanti, Lusiana, and Prasetyo, 2017). The increase in durability is due to the addition of adhesive which affects the mechanical resistance of the briquettes.

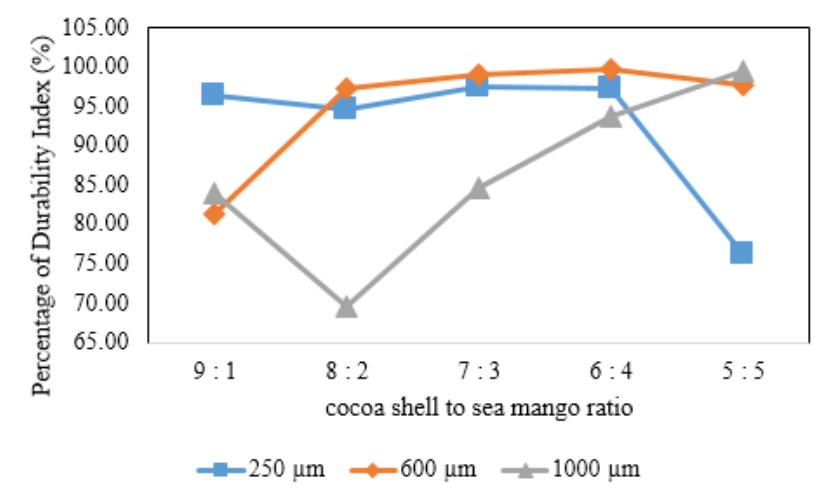

Fig. 6 Percentage of durability index

The percentage water resistance index (PWRI) is shown in Figure 7. Figure 7 shows that the smaller the particles, the higher the PWRI value. Briquettes with large particle sizes have large inter-particle bores so that the briquettes absorb water more easily. Briquettes with a particle size of $1000 \mu \mathrm{m}$ had a low PWRI average value of $87 \%$. This finding is consistent with another research, which states that briquettes with a larger particle size are more difficult to seal and that there are many void fractions (Sibarani, 2016).

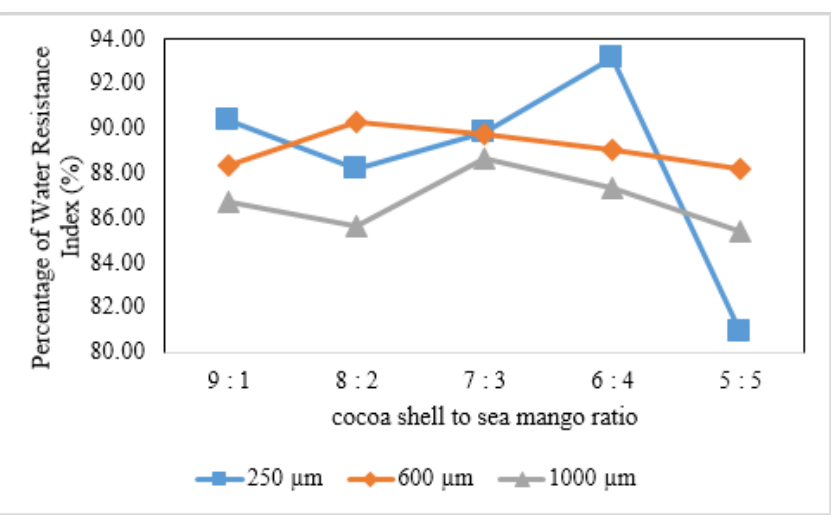

Fig. 7 Percentage of water resistance

The results of the burning rate (BR) analysis are shown in Figure 8. From Figure 8 samples with a particle size of $250 \mu \mathrm{m}$ have a fairly high BR value, especially in the sample with a mixture ratio of 9:1. The smaller particle size allows the briquettes to be denser so that the briquette cavities are smaller. It will be more difficult for oxygen to move through the small cavity in the briquette and thus the briquette has a slower burning rate. This is in line with other research that states that the denser briquette will have a longer burning rate (Sibarani, 2016).

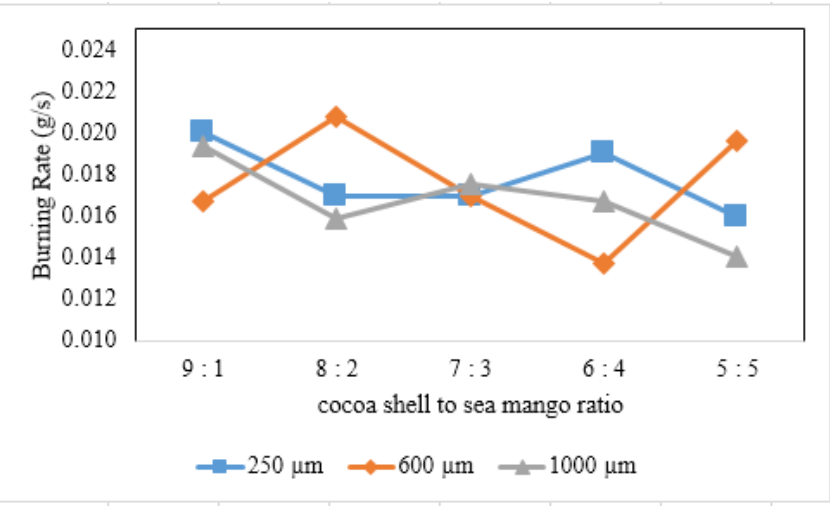

Fig 8. Burning rate

The results of specific fuel consumption are shown in Figure 9. For the SFC result, Figure 9 shows that the SFC value tends to decrease with increasing content of sea mango. The highest SFC value is found in the sample to a particle size of $250 \mu \mathrm{m}$ which is $0.05 \mathrm{~g} / \mathrm{mL}$. SFC value of the sample relates to its calorific value. Lower SFC value Mans the sample has higher calorific value. It is found from the literature that sea mango has higher calorific value than the cocoa shell as such the increase of sea mango content tends to decrease the SFC value (Fardani and Tjahjani, 2018). Whereas for briquettes with particle sizes of $1000 \mu \mathrm{m}$ and $600 \mu \mathrm{m}$, the SFC values continued to decrease, respectively 0.048 and $0.05 \mathrm{~g} / \mathrm{mL}$.

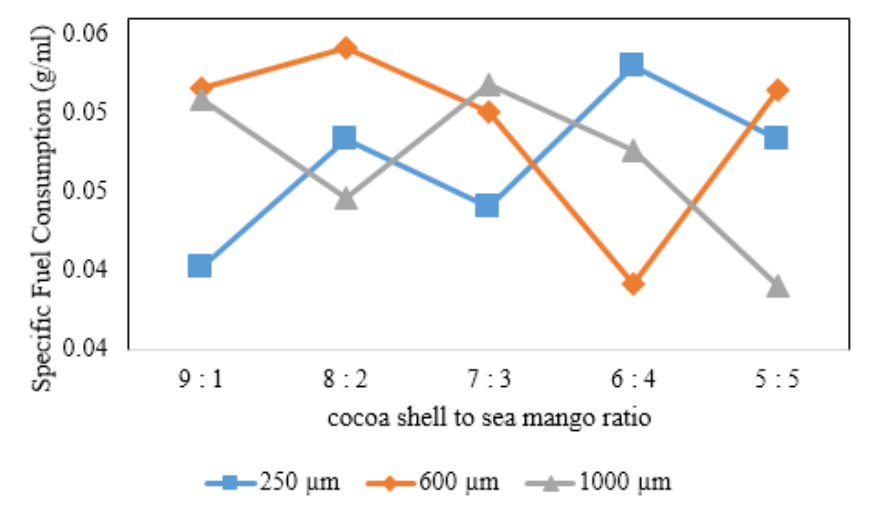

Fig 9. Specific fuel consumption

The water boiling test (WBT) result is shown in Figure 10. The water temperature increases as the ratio of sea mango content increases. This is due to sea mango charcoal has a higher calorific value than cocoa shell charcoal (Fardani and Tjahjani, 2018). The samples with particle sizes of 250 and $600 \mu \mathrm{m}$ have a high average WBT value of 59.47 and $59.33^{\circ} \mathrm{C}$. This is because the particle size affects the heating rate. The finer powder would combust faster so that 
it can deliver the energy faster. The process to increase the calorific value.

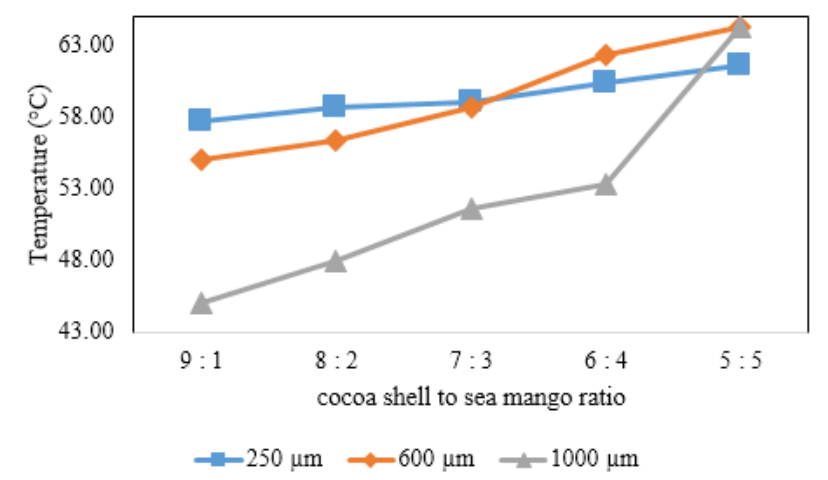

Fig 10. water boiling test

\subsection{Students' Demographics}

The subject of this research is 30 students from one of the vocational schools in Garut, Indonesia. The average value of science subjects (Mathematics, Chemistry, Biology, Physics, and Vegetable Product Processing Technology) is taken as an assessment to determine the readiness of students in the learning process of making bio-charcoal briquettes. Each student shows different characteristics of interest and this confirms that students' interest in the subject is based on students' curiosity and satisfaction. Data is also used as a basis for the recognition of intelligence and assessment of effective learning methods (Hidayat, Rahmat, Fattah, Rochyadi, Nandiyanto, and Maryanti, 2020).

Distribution of science subject average score of the subjects is shown in Figure 11. From the data, it can be found that the average score is 80.57 with a standard deviation of 4.5. It indicates that subjects are sufficiently capable to learn the briquetting process.

Distribution of the IQ score of the subjects is shown in Figure 12. The average IQ score is 99, which means the subjects are at a normal or average level. Based on the IQ score, it could be concluded that the students can follow the learning although some subjects might sometimes encounter difficulties.

\subsection{Teaching Results}

Average Test Score Data before and after the subjects are exposed with Learning videos and E-Module is shown in Table 2. Question for the test is in the form of a statement and the subjects are asked to determine whether the statement is correct. The data from table 2 are then analyzed by using a boxplot as shown in Figure 13. From Figure 6, it can be seen that the average of the pretest, learning video posttest, and e-module posttest are 66, 75 and 90 respectively. This is because students still have insufficient knowledge about bio charcoal briquettes. However, after learning from the instructional video, the post-test value increased by an average of 75 . The score of the test results through the learning videos increase by $13.6 \%$. This result is quite comparable with previous research in which the score of the test results increased by $8.3 \%$ with the same method
(Nandiyanto, A. B. D., Raziqi, G. Y., Dallyono, R., and Sumardi, K., 2020). Furthermore, when the use of learning video is combined with e-module the score increases more significantly to a value of 90 or about $36 \%$. This result is comparable with other research which also uses learning video and e-module where the score increases $34 \%$ (Sutirman, 2019). The higher score of the e-module posttest indicates that the e-module is more effective than learning video to increase the knowledge of the subjects regarding the briquetting process. To validate the results further statistical tests are applied which are normality test, homogeneity test, and t-test.

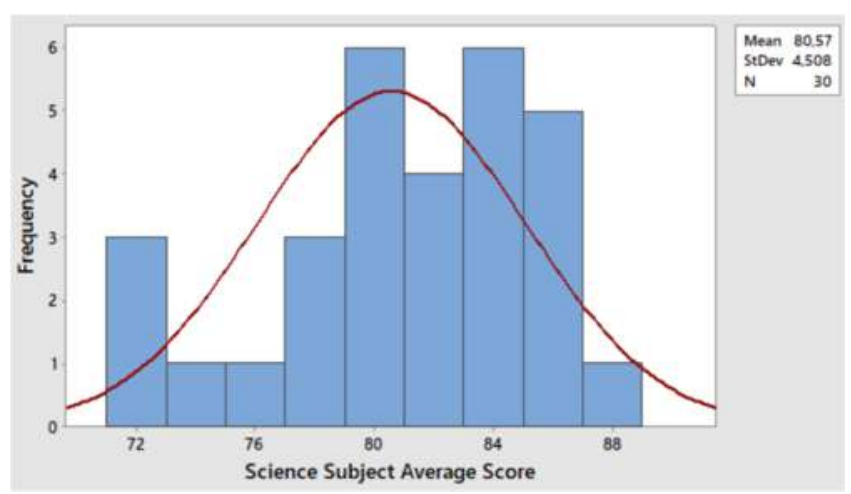

Fig. 11 science subject average score

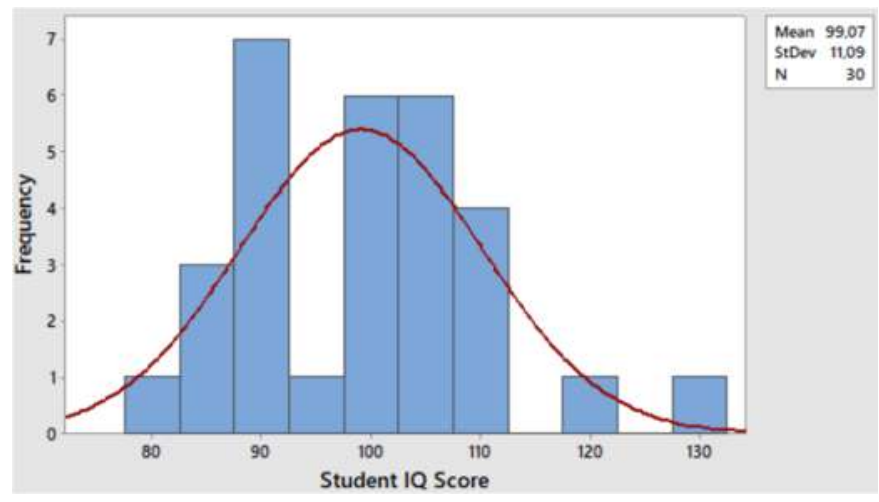

Fig. 12 student IQ score

Table 2. Average Test Score Data before and after the subjects are exposed with Learning videos and E-Module

\begin{tabular}{|c|c|c|c|c|}
\hline \multirow[b]{2}{*}{ No } & \multirow[b]{2}{*}{ Statement Question } & \multirow[b]{2}{*}{ Pretest } & \multicolumn{2}{|c|}{ Posttest } \\
\hline & & & $\begin{array}{c}\text { Learning } \\
\text { instructional } \\
\text { video } \\
\end{array}$ & $\begin{array}{c}\text { e- } \\
\text { Module }\end{array}$ \\
\hline 1. & $\begin{array}{l}\text { Biomass Briquettes are } \\
\text { sustainable alternative } \\
\text { energy sources }\end{array}$ & 93.33 & 96.67 & 100.00 \\
\hline 2. & $\begin{array}{l}\text { Carbonization is the } \\
\text { process of converting } \\
\text { organic material into } \\
\text { charcoal. }\end{array}$ & 83.33 & 83.33 & 80.00 \\
\hline 3. & $\begin{array}{l}\text { The number of volatile } \\
\text { compounds in the } \\
\text { briquette is influenced by } \\
\text { the temperature when } \\
\text { charcoal/carbonization. }\end{array}$ & 60.00 & 70.00 & 86.67 \\
\hline 4. & $\begin{array}{l}\text { The mechanical strength } \\
\text { of briquettes (brittleness) }\end{array}$ & 73.33 & 80.00 & 90.00 \\
\hline
\end{tabular}


is influenced by the type and number of binders

Table 2. (continued) Data on the Pretest-Posttest Value of Learning Instructional videos and E-Module Posttest

\begin{tabular}{|c|c|c|c|c|}
\hline \multirow[b]{2}{*}{ No } & \multirow[b]{2}{*}{ Question } & \multirow[b]{2}{*}{ Pretest } & \multicolumn{2}{|c|}{ Posttest } \\
\hline & & & $\begin{array}{c}\text { Learning } \\
\text { instructional } \\
\text { video } \\
\end{array}$ & $\begin{array}{c}\text { e- } \\
\text { Module }\end{array}$ \\
\hline 5. & $\begin{array}{l}\text { In the carbonization } \\
\text { process, the length of time } \\
\text { required depends on the } \\
\text { size of the briquette itself. } \\
\text { the larger the briquette } \\
\text { size, the less time it takes } \\
\text { in the carbonization } \\
\text { process. }\end{array}$ & 46.67 & 70.00 & 90.00 \\
\hline 6. & $\begin{array}{l}\text { The more air that enters at } \\
\text { the time of carbonization } \\
\text { will cause the charcoal } \\
\text { produced to be oxidized } \\
\text { and reduce the quality of } \\
\text { the briquettes. }\end{array}$ & 63.33 & 66.67 & 83.33 \\
\hline 7. & $\begin{array}{l}\text { The denser the adhesive } \\
\text { liquid will result in a } \\
\text { longer carbonization } \\
\text { process. }\end{array}$ & 60.00 & 70.00 & 93.33 \\
\hline 8. & $\begin{array}{l}\text { The larger the size of the } \\
\text { carbonized raw material, } \\
\text { the easier it is to briquette. }\end{array}$ & 43.33 & 83.33 & 90.00 \\
\hline 9. & $\begin{array}{l}\text { The higher the content of } \\
\text { the wood substance in the } \\
\text { briquette raw material will } \\
\text { result in more charcoal } \\
\text { produced. }\end{array}$ & 86.67 & 73.33 & 96.67 \\
\hline 10. & $\begin{array}{l}\text { In the carbonization } \\
\text { process, it must be in an } \\
\text { inert state so that oxidation } \\
\text { does not occur. }\end{array}$ & 83.33 & 83.33 & 90.00 \\
\hline 11. & $\begin{array}{l}\text { The carbonization process } \\
\text { requires a very high } \\
\text { temperature. }\end{array}$ & 36.67 & 73.33 & 83.33 \\
\hline 12. & $\begin{array}{l}\text { Based on the nature of } \\
\text { briquettes in absorbing } \\
\text { water, charcoal briquettes } \\
\text { are less } \\
\text { absorbent/hydrophobic } \\
\text { than biomass briquettes. }\end{array}$ & 70.00 & 76.67 & 90.00 \\
\hline 13. & $\begin{array}{l}\text { When it comes to igniting } \\
\text { briquettes, biomass } \\
\text { briquettes take longer to } \\
\text { ignite than charcoal } \\
\text { briquettes. }\end{array}$ & 66.67 & 80.00 & 100.00 \\
\hline 14. & $\begin{array}{l}\text { Based on the } \\
\text { storage/storage duration, } \\
\text { biomass briquettes have a } \\
\text { longer duration than } \\
\text { charcoal briquettes. }\end{array}$ & 60.00 & 63.33 & 86.67 \\
\hline 15. & $\begin{array}{l}\text { The higher the SFC, the } \\
\text { better the quality of the } \\
\text { briquette (more } \\
\text { economical). }\end{array}$ & 70.00 & 56.67 & 93.33 \\
\hline
\end{tabular}

To validate the statistical assumption the data are distributed normally in student learning outcomes, pretest, learning video posttest, and e-module posttest is analyzed using a normality test. The normality test used is the
Kolmogorov-Smirnov test and the Shapiro Wilk test. The following is the normality test result data shown in Table 4. From the normality test, the significance value in the pretest, posttest instructional video, and posttest e-module data groups is normally distributed due to the significance value (sig) of the pretest, posttest instructional video, and posttest e-module data $>0.05$. After the normality test, the homogeneity test was conducted.

The homogeneity test is only used in the parametric test to verify the discrepancies between the two groups or groups of different subjects or data sources. The homogeneity test is therefore required as a hypothesis of an independent t-test. Table 4 displays the results of the homogeneity test with a pvalue (sig) of 0.01 where $>0$. which means that there is a correlation in variants between data groups or that is homogeneous. The dfl and df 2 values are used to compare data in table F. If the data is normally distributed and homogeneous, then the test can be continued with the Independent t-test.

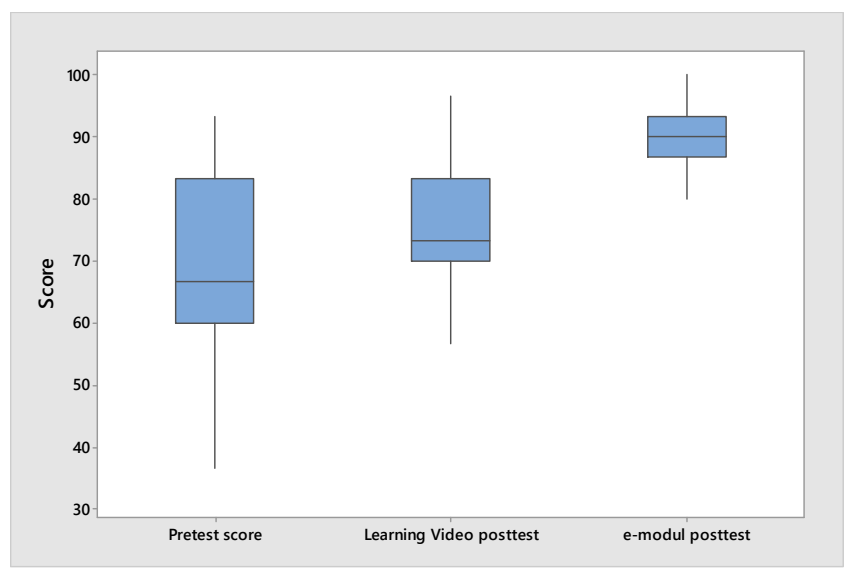

Fig. 13 Boxplot Analysis for the Test Score Result

Table 5 shows the results of the Independent t-test analysis. Both learning video posttest and e-module posttest are compared with the pretest. The result in Table 6 shows that $\mathrm{p}$-value for learning video posttest is 0.08 while the $\mathrm{p}$ value for e-module posttest is 0.00 . These results indicate that at a confidence level of $95 \%$, only e-module posttest gave a significant increase to the objects' score.

The use of instructional video and e-module will enhance student learning outcomes, as e-module provide wider and more detailed content as well as previous student experience from learning using the instructional video helps students learn.

Table 4. Homogeneity Test Results

\begin{tabular}{|l|c|c|c|}
\hline & df1 & df2 & Sig. \\
\hline Based on Mean & 2 & 42 & 0.01 \\
\hline Based on Median & 2 & 42 & 0.01 \\
\hline $\begin{array}{l}\text { Based on Median and with } \\
\text { adjusted df }\end{array}$ & 2 & 28.96 & 0.01 \\
\hline Based on trimmed mean & 2 & 42 & 0.01 \\
\hline
\end{tabular}

Table 5. Result of Independent t-test 


\begin{tabular}{|l|c|c|c|c|c|}
\hline & $\mathrm{t}$ & $\mathrm{df}$ & $\begin{array}{c}\mathrm{p} \text {-value } \\
\text { (2-tailed) }\end{array}$ & $\begin{array}{c}\text { Mean } \\
\text { Difference }\end{array}$ & $\begin{array}{c}\text { Std. Error } \\
\text { Difference }\end{array}$ \\
\hline $\begin{array}{l}\mathrm{t} \text {-test analysis for } \\
\text { learning video } \\
\text { posttest }\end{array}$ & -1.76 & 28 & 0.08 & -8.67 & 4.91 \\
\hline $\begin{array}{l}\text { t-test analysis for e- } \\
\text { module posttest }\end{array}$ & -5.12 & 28 & 0.00 & -15.11 & 2.95 \\
\hline
\end{tabular}

\section{Conclusion}

Variations in particle size and sea mango content affect the quality of briquettes. It related to the lignocellulose content of the sea mango, which is higher than the lignocellulose content of cocoa shells. Higher lignocellulose content causes increase in the burning rate as well as the value of the water boiling test and decrease specific fuel consumption. Briquettes with small particle sizes have high values of relaxed density, relaxation ratio, and percentage of durability index. However, the compressed density and the percentage of moisture content are low due to the high density of briquettes on smaller particles. The improvement of learning outcomes by using e-learning video is not significant when it is compared with the result from the emodule. Based on the result, it can be concluded that the emodule is more effective than learning video for the student because it can cover wider and deeper materials. However, learning video is still necessary to be given to the students so that they may have a better visual experience regarding the briquetting process.

\section{References}

Asrial. (2019). Multimedia innovation 4.0 in education: Emodul ethnoconstructivism. Universal Journal of Educational Research, 7(10), 2098-2107

Ben-Ghedalia, D., and Miron, J. (1981). The effect of combined chemical and enzyme treatments on the saccharification and in vitro digestion rate of wheat straw. Biotechnology and bioengineering, 23(4), 823-831.

Bjork, R. A., Dunlosky, J., and Kornell, N. (2013). Selfregulated learning: Beliefs, techniques, and illusions. Annual review of psychology, 64, 417- 444.

Brame, C. J. (2016). Effective educational videos: Principles and guidelines for maximizing student learning from video content. CBE-Life Sciences Education, 15(4), 1-6.

Damayanti, R., Lusiana, N., and Prasetyo, J. (2017). Studi pengaruh ukuran partikel dan penambahan perekat tapioka terhadap karakteristik biopelet dari kulit coklat (Theobroma Cacao L.) sebagai bahan bakar alternatif terbarukan. Teknotan: Jurnal Industri Teknologi Pertanian, 11(1), 51-60.

Direktorat Pembinaan SMA. Ditjen Pendidikan Dasar dan Menengah (2017). Panduan Praktis Penyusunan E-Modul Tahun 2017. Direktorat Jenderal Pendidikan Dasar Dan
Menengah Kementerian Pendidikan Dan Kebudayaan, Jakarta.

Fardani, A. R., and Tjahjani, S. (2018). Pembuatan dan karakterisasi campuran kulit durian (durio zibethinus murr.) dan buah bintaro (cerberra odollam g.) sebagai bahan bakar briket production and characterization peel of durian (durio zibethinus murr.) and bintaro (cerberra odollam g.) mixture. Unesa Journal of Chemistry, 7(3), 112-118.

Fourlilla, and Fauzi, A. (2019). Develop Analysis With Electronic Module. J. Phys. Ser : Conf. Ser., 011(085), 0-4.

Hambali E. (2007), Teknologi Bioenergi, Agromedia, Jakarta

Hasan, R., Tedja, T., Riani, E., and Sugiarti, S. (2016). Pengaruh Aktivasi Fisika dan Kimia Arang Aktif Buah Bintaro Terhadap Daya Serap Logam Berat Krom. Biopropal Industri, 7(1), 35-45.

Hidayat, D. S., Rahmat, C., Fattah, N., Rochyadi, E., Nandiyanto, A. B. D., and Maryanti, R. (2020). Understanding archimedes law: What the best teaching strategies for vocational high school students with hearing impairment. Journal of Technical Education and Training, 12 (1), 229-237.

Istuningsih, W., Baedhowi, and Sangka, K. B. (2018). The use of electrinic module for learning effectiveness. IJERE, 03(03), 75-85

Martynis, M., Sundari, E., and Sari, E. (2012). Pembuatan biobriket dari limbah cangkang kakao. Jurnal Litbang Industri, 2(1), 35-41.

Nandiyanto, A. B. D., Asyahidda, F. N., Danuwijaya, A. A., Abdullah, A. G., Amelia, N., Hudha, M. N., and Aziz, M. (2018). Teaching "nanotechnology" for elementary students with deaf and hard of hearing. Journal of Engineering Science and Technology, 13(5), 1352-1363.

Nandiyanto, A. B. D., Raziqi, G. Y., Dallyono, R., \& Sumardi, K. (2020). Experimental Demonstration for Enhancing Vocational Students' Comprehension on Heat Transfer through Conduction and Radiation of Light Bulb. Journal of Technical Education and Training, 12(3), 189195.

Nasution, M.G., (2011), Perbedaan Hasil Belajar Siswa Menggunakan Media Audiovisual Dan Media Charta Pada Pembelajaran Biologi Materi Pokok Ekosistem Di Kelas X SMA PAB 8 Saentis Tahun Pembelajaran 2010/2011, Skripsi, FMIPA, Unimed, Medan.

Priyanto, A., Hantarum, H., and Sudarno, S. (2018). Pengaruh Variasi Ukuran Partikel Briket Terhadap Kerapatan, Kadar Air, Dan Laju Pembakaran Pada Briket Kayu Sengon. In Prosiding Seminar Nasional Sains dan Teknologi Terapan, 541-546

Riedl, H. (1977). E-Modul-Bestimmung kollagener Fasern. Colloid and Polymer Science Kolloid Zeitschrift and amp; Zeitschrift für Polymere, 255(2), 174-175. 
Rizaldi, M. S., Budiman, B., and Moonti, S. W. (2019). Efektivitas Briket Daun Ketapang Terminalia Catappa Dan Kulit Kakao Theobroma Cacao L Sebagai Bioarang. Jurnal Kolaboratif Sains, 1(1), 11-18

Schacter, D. L., \& Szpunar, K. K. (2015). Enhancing attention and memory during videorecorded lectures. Scholarship of Teaching and Learning in Psychology, 1(1), 60-71.

Schunk, Dale. (2012). Learning Theories. Jakarta: Pustaka Pelajar.

Seidel, N. (2012). E-learning module on integrated water resources management: Concepts and tools for the realization of a hyperinstructional video-based learning environment. Lecture Notes in Informatics (LNI), Proceedings - Series of the Gesellschaft fur Informatik (GI), 207, 291-302.

Setiowati, R., and Tirono, M. (2014). Pengaruh variasi tekanan pengepresan dan komposisi bahan terhadap sifat fisis briket arang. Jurnal Neutrino: Jurnal Fisika Dan Aplikasinya, 7(1), 23-31.

Sibarani, F. A. S. (2016). Pengaruh Perbandingan Tempurung Kelapa Dan Eceng Gondok Serta Variasi Ukuran Partikel Terhadap Karakteristik Briket. Jurnal Teknik Kimia USU, 5(3), 56-61.

Suarsana, I. M. (2013). Pengembangan e-modul berorientasi pemecahan masalah untuk meningkatkan keterampilan berpikir kritis mahasiswa. JPI (Jurnal Pendidikan Indonesia), 2(2), 264-275.

Suryani, I., and Dahlan, M. H. (2012). Pembuatan briket arang dari campuran buah bintaro dan tempurung kelapa menggunakan perekat amilum. Jurnal Teknik Kimia, 18(1), 24-29.

Sutirman, S. (2019). The Differences in the Effect of Using Video and Modules as Media in Learning Electronic Record Management. TEM Journal, 8(3), 984-991.

Syahrial (2020). Impact E-modul ethnoconstructivism: Attitude and amp; motivation. International Journal of Scientific and Technology Research, 9(4), 3752-3757.

$\begin{aligned} & \text { Wibowo, E. (2018). Modul Elektronik } \\ & \text { Guna }\end{aligned}$
$\begin{aligned} & \text { Mengembangkan } \\ & \text { http://repository.radenintan.ac.id/3420/1/skripsi fix edi.pdf }\end{aligned}$

